BACKGROUND: The model of pleurisy induced by carrageenan exhibits a biphasic response $(4$ and $48 \mathrm{~h}$ ) and permits the quantification of exudate, cell migration and certain enzymes such as myeloperoxidase (MPO) and adenosine-deaminase (ADA) that are markers of activated leukocytes.

Aims: The present study evaluates whether there exists, in the pleurisy model, a significant inhibition of ADA and MPO enzymes, leukocyte kinetics and other markers of inflammation [nitric oxide (NO) levels, exudation] caused by methotrexate treatment by the intraperitoneal (i.p.) route.

Metbods: The pleurisy was induced by carrageenan $(1 \%)$ in mice, and the parameters were analyzed 4 and $48 \mathrm{~h}$ after.

Results: After the induction of inflammation $(4 \mathrm{~h})$, methotrexate $(20 \mathrm{mg} / \mathrm{kg}$, i.p., $24 \mathrm{~h}$ before pleurisy induction) inhibited the leukocyte infiltration $(p<$ $0.05)$, NO levels and MPO activity $(p<0.01)$, but not ADA activity and fluid leakage $(p>0.05)$. Regarding the second phase of pleurisy $(48 \mathrm{~h})$, methotrexate ( $40 \mathrm{mg} / \mathrm{kg}$, i.p., $0.5 \mathrm{~h}$ before pleurisy induction) inhibited the leukocyte infiltration $(p<0.05)$, fluid leakage, NO levels $(p<0.01)$, and ADA and MPO activity $(p<$ 0.05).

Conclusions: These findings support the evidence that the acute administration of methotrexate has an important systemic anti-inflammatory activity in the studied inflammatory model. This effect was due to a significant inhibition on both neutrophil and mononuclear cells, being less marked in relation to exudation $48 \mathrm{~h}$ after. In relation to the enzymes studied and to NO levels, the findings support the evidence that methotrexate inhibits both enzymes (MPO and ADA) from leukocytes at the site of injury, thus reflecting the activation of both neutrophils and lymphocytes, respectively. Furthermore, the inhibiting effect on NO in both phases of pleurisy induced by carrageenan $(4$ and $48 \mathrm{~h}$ ) indicates that methotrexate acts on constitutive and/or inducible NO synthases by means of different cells of the pleural cavity.

Key words: Adenosine-deaminase, Myeloperoxidase, Mouse, Pleurisy, Inflammation, Exudation, Nitric oxide

\section{Effects of methotrexate upon inflammatory parameters induced by carrageenan in the mouse model of pleurisy}

\author{
Eduardo Monguilhott Dalmarco ${ }^{1}$, Tânia Silvia \\ Fröde $^{1, C A}$ and Yara Santos Medeiros ${ }^{2}$
}

${ }^{1}$ Department of Clinical Analysis, Center of Health Sciences, and ${ }^{2}$ Department of Pharmacology, Center of Biological Sciences, Universidade Federal de Santa Catarina, Campus Universitário - Trindade, 88040-970, Florianópolis, SC, Brazil

\footnotetext{
${ }^{\mathrm{CA}}$ Corresponding Author

Fax: +55 $48244-0936$

E-mail: taniafrode@zipmail.com.br
}

\section{Introduction}

Methotrexate, a folate antagonist, is a potent antiinflammatory agent. ${ }^{1}$ Because of its efficiency as an immunosuppressive agent, which at low doses does not affect cellular proliferation, it has been used in the treatment of rheumatoid arthritis. ${ }^{2}$ More recently, it has also been used in post-transplant therapy to successfully reverse recalcitrant rejection in cardiac transplant patients. ${ }^{3,4}$

The mechanisms by which methotrexate inhibits both acute and chronic inflammation remains controversial. Evidence indicates that methotrexate treatment decreases neutrophil-endothelial adhesion in vitro by modulating the expression of integrins. Furthermore, this drug also suppresses neutrophil accumulation and exudation in the reverse passive Arthus reaction of rat dorsal skin, nitric oxide (NO) production by inducible nitric oxide synthase (iNOS) in murine lung epithelial cells in vitro, and decrease of the prostaglandin $\mathrm{E}_{2}$ release in the cultured human rheumatoid synoviocytes, ${ }^{5-7}$ among others. It has been proposed that these effects are probably mediated, in part, by adenosine release from endothelial cells, followed by adenosine receptor occupancy on macrophages and lymphocytes, since it is reversed by adenosine-deaminase (ADA). ${ }^{8,9}$ The adenosine released at inflamed sites interacts with specific 
receptors on the inflammatory cells to diminish inflammation and tissue injury.

In the present study, we evaluated the acute antiinflammatory effects of methrotrexate in the inflammatory model of mouse pleurisy induced by carrageenan. The inflammatory profile of this model is characterized by an early ( $4 \mathrm{~h})$ and a late (48h) inflammatory phases in response to the carrageenan challenge, where several mediators [such as histamine, bradykinin, prostaglandins, platelet-acether factor, myeloperoxidase (MPO), ADA and leukotrienes] are involved. ${ }^{10-12}$ In addition to the evaluation of both the early ( $4 \mathrm{~h})$ and late ( $48 \mathrm{~h}$ ) amounts of both leukocyte migrations and leakage influxes into the pleural cavity, nitrate/nitrite concentrations that indirectly reflect NO production ${ }^{13}$ and MPO and ADA activities were also measured in the pleural fluid, and compared with those found in a non-treated mouse.

\section{Methods}

\section{Animals}

Non-fasted adult Swiss mice of both sexes (18-25 g), aged 2 months, were used throughout the experiments. They were housed in accordance with institutional animal care (temperature $21 \pm 2^{\circ} \mathrm{C}$, under a light/dark cycle of $12 \mathrm{~h}$ ) and were freely fed on standard rodent chow and water.

Two groups of animals were studied: pre-treated, and untreated with methotrexate prior to the induction of pleurisy with carrageenan. In parallel, two or three animals that had received an injection of either sterile saline by the intrapleural route or methotrexate by the intraperitoneal (i.p.) route were included in all experimental groups (results not shown). In preliminary experiments (results not shown), several doses of methotrexate and different intervals of pre-treatment were tested. Based on these results, the period $0.5 \mathrm{~h}$ prior to carrageenan injection was chosen for use in the experiments described.

In a first set of experiments, animals were treated $0.5 \mathrm{~h}$ before pleurisy induction with different doses of methotrexate $(1-40 \mathrm{mg} / \mathrm{kg}$, i.p.) and the inflammatory parameters were analyzed 4 and $48 \mathrm{~h}$ after carrageenan injection. In other experiments, animals were pre-treated $(0.5-48 \mathrm{~h})$ with methotrexate $(20$ or $40 \mathrm{mg} / \mathrm{kg}$, i.p.) and the same inflammatory parameters were evaluated 4 and $48 \mathrm{~h}$ after pleurisy induction.

\section{Experimental design}

\section{Induction and analysis of pleurisy}

As previously reported, ${ }^{11,14}$ the mouse pleurisy was induced by a single intrapleural injection of $0.1 \mathrm{ml}$ of sterile saline plus carrageenan (1\%). Since the pleurisy caused by carrageenan exhibits a biphasic response ( 4 and $48 \mathrm{~h}$ ), both interval points were chosen to analyze the studied parameters.

After killing the animals with an overdose of ether, the thorax was opened and the pleural cavity was washed with $1.0 \mathrm{ml}$ of sterile phosphate-buffered saline (PBS) (pH 7.6; composition, $137 \mathrm{mmol}$ of $\mathrm{NaCl}$ and $2.7 \mathrm{mmol}$ of $\mathrm{KCl}$ ) containing heparin $(20 \mathrm{IU} / \mathrm{ml})$. Several samples of the pleural lavage were collected for further determination of both MPO and ADA activities, ${ }^{15,16}$ exudation levels and NO concentrations, ${ }^{13}$ as well as total and differential leukocyte contents. Total leukocyte counts were performed on an automatic counting machine (Beckman Coulter, Brea, California, USA), whereas cytospin preparations of pleural washing were stained with May-Grunwald-Giemsa for the differential count of leukocytes, which was performed under an immersion objective. According to the experimental protocol, another two groups of animals that had been injected $1 \mathrm{~h}$ previously with a solution of Evans blue dye ( $25 \mathrm{mg} / \mathrm{kg}$, i.v.), in order to evaluate the degree of exudation in the pleural cavity (Elisa-Reader; Organon, Roseland, New Jersey, USA) at $600 \mathrm{~nm}$, were included in both the treated and the non-treated methotrexate groups.

\section{Determination of nitrate/nitrite concentration}

NO was measured as its breakdown product of nitrite $\left(\mathrm{NO}_{2}{ }^{-}\right)$and nitrate $\left(\mathrm{NO}_{3}{ }^{-}\right)$using the Griess method. ${ }^{15}$ Samples of the pleural lavage obtained from control and treated animals that did not receive Evans blue dye injection were separated and stocked at $-70^{\circ} \mathrm{C}$. On the day of the experiments, the samples were thawed and de-proteinized by the addition of $6 \mathrm{mM}$ sodium hydroxide and $0.6 \%$ of zinc sulfate. Afterwards, $250 \mu$ l of pleural lavage was diluted in $30 \mu 1$ of ammonium format, $30 \mu 1$ of hydrate disodium hydrogen phosphate-12 and $30 \mu 1$ of Escherichia coli (EC ATCC 25922; diluted 1: 7 in PBS), and were then incubated for $2 \mathrm{~h}$ at $37^{\circ} \mathrm{C}$. After centrifugation at $50 \times$ $g$ for $5 \mathrm{~min}, 250 \mu \mathrm{l}$ of the supernatant was transferred to cuvettes and the same volume of fresh Griess reagent [5\% (vol/vol) of $\mathrm{H}_{3} \mathrm{PO}_{4}, 1 \%$ of sulfanilic acid and $0.1 \%$ of $N$-(1-naphythyl) ethylenediamine] was added and incubated for $10 \mathrm{~min}$ at room temperature. The reaction of $\mathrm{NO}_{2}{ }^{-}$with this reagent produced a pink color, which was quantified at $543 \mathrm{~nm}$ against standards $(0-150 \mu \mathrm{M})$ on an Elisa-reader (Organon).

\section{Enzymatic assays}

In-house assays of both MPO and ADA were employed according to the methods developed by RAO et al. ${ }^{16}$ and Giusti and Galanti. ${ }^{17}$ Using conventional reagents, each enzymatic concentration was estimated by means of colorimetric measurements (absorbances of 450 and $630 \mathrm{~nm}$, respectively) in an Organon, USA spectrophotometer (U-2001; Organon, USA). One unit of MPO is defined as the activity of the enzyme that oxides one molecule of $\mathrm{H}_{2} \mathrm{O}_{2}$ per minute, 

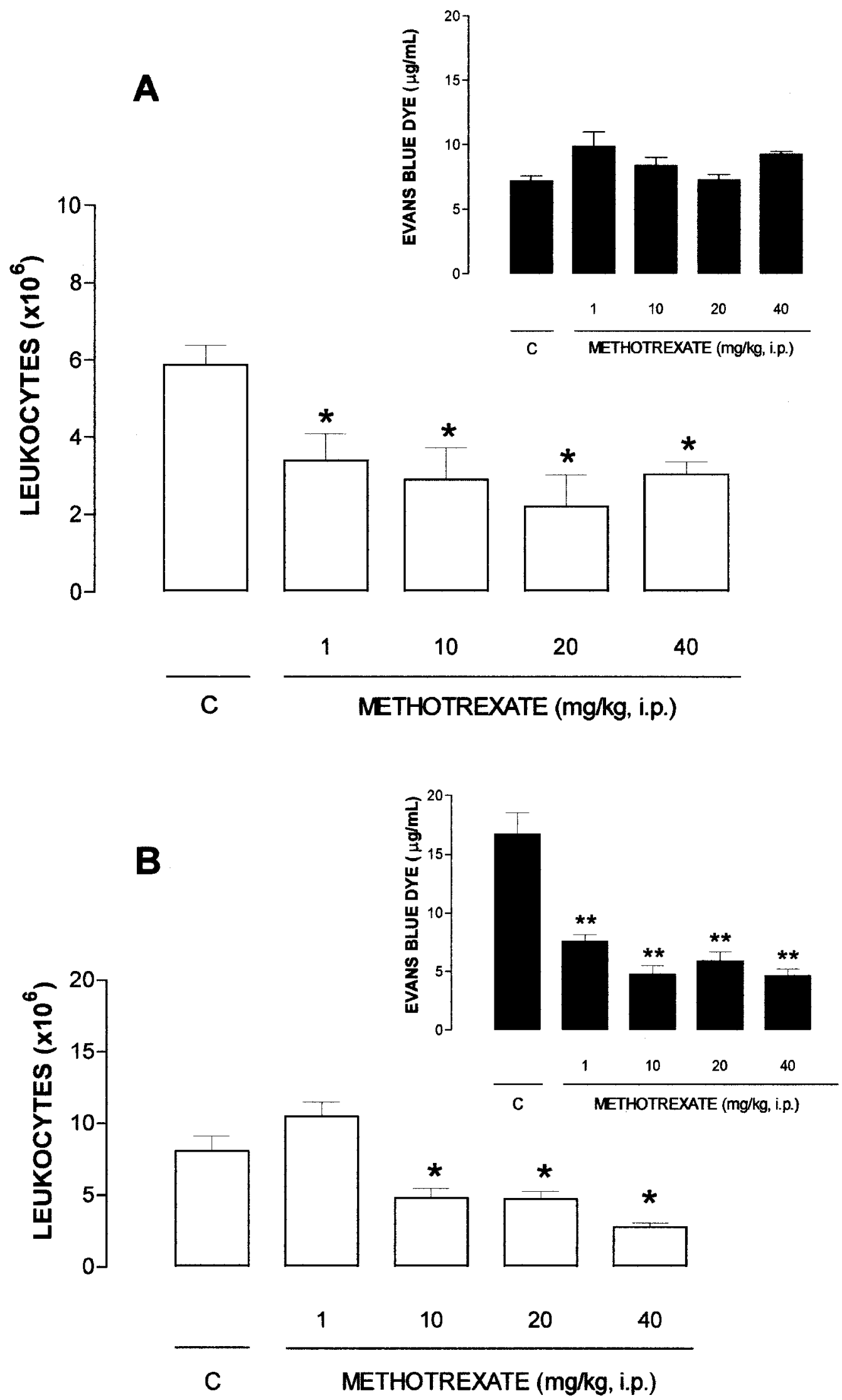

C METHOTREXATE $(\mathrm{mg} / \mathrm{kg}$, i.p.)

FIG. 1. Effect of methotrexate on early $(4 \mathrm{~h})$ or late $(48 \mathrm{~h})$ phases of the mouse model of pleurisy induced by carrageenan (1\%). (A) Effect of methotrexate $(20 \mathrm{mg} / \mathrm{kg}$, i.p., $24 \mathrm{~h}$ prior) on the early $(4 \mathrm{~h})$ phase of inflammatory response upon the leukocyte migration. (B) Effect of methotrexate $(40 \mathrm{mg} / \mathrm{kg}$, i.p., $0.5 \mathrm{~h}$ prior) on the late $(48 \mathrm{~h})$ phase of inflammatory process. Insets: Effect of methotrexate upon exudation levels under the same conditions. C, Animals treated only with carrageenan. Each group represents the mean of six to 10 animals, bars represent the SEM. ${ }^{*} p<0.05,{ }^{*} p<0.01$. 
whereas one unit of ADA is equivalent to the amount of enzyme required to release 1 millimole of ammonia per minute. Results are expressed as milli-units per microliter (MPO) and units per liter (ADA).

\section{MPO assay}

Standard samples with different concentrations of MPO (from human neutrophils) (M6908; Sigma, St Louis, MO, USA) were prepared in order to obtain a standard curve in the range of $0.07-140 \mathrm{mU} / \mathrm{ml}$. Pleural aliquots $(40 \mu \mathrm{l})$ and standards were transferred to cuvettes and the reaction was initiated with the addition of $360 \mu 1$ of assay buffer $(0.167 \mathrm{mg} / \mathrm{ml}$ of $o$-dianisidine $2 \mathrm{HCl}$ and $0.0005 \% \mathrm{H}_{2} \mathrm{O}_{2}$ ). The reaction was stopped with $1 \%$ sodium azide. Afterwards, the samples were centrifuged at $50 \times g$ for $5 \mathrm{~min}$, the supernatants were separated, and the rates of changes in absorbancy were determined. MPO activity was estimated by interpolation from the standard curve described earlier. Samples in which the levels of MPO were above the higher limit of detection $(140 \mathrm{mU} / \mathrm{ml})$ were diluted (two-fold to five-fold) and the concentrations were corrected for the two-fold to five-fold dilution, whereas results below the lower limit of detection were expressed as $0.7 \mathrm{mU} / \mathrm{ml}$.

\section{ADA assay}

Initially, standard samples (final volume of $500 \mu \mathrm{l}$ ) with different volume concentrations of $\mathrm{NaH}$ ${ }_{2} \mathrm{PO}_{4} \cdot \mathrm{H}_{2} \mathrm{O} \quad(35 \mathrm{mM}), \quad \mathrm{Na}_{2} \mathrm{HPO}_{4} \cdot \mathrm{H}_{2} \mathrm{O} \quad(15 \mathrm{mM})$ and $\mathrm{NH}_{3} \mathrm{SO}_{4}(15 \mathrm{mM})$ were prepared to obtain a standard curve in the range of 10-50 U/1. Pleural fluid samples $(20 \mu 1)$ were transferred to cuvettes and the reaction was initiated by the addition of adenosine phosphatebuffered solution [pH 6.5, $500 \mu \mathrm{l}$; composition, $\mathrm{NaH}-$ ${ }_{2} \mathrm{PO}_{4} \cdot \mathrm{H}_{2} \mathrm{O}(35 \mathrm{mM}), \mathrm{Na}_{2} \mathrm{HPO}_{4} \cdot 12 \mathrm{H}_{2} \mathrm{O}(15 \mathrm{mM})$ and adenosine $(0.5 \mathrm{mM})]$. After incubation for $1 \mathrm{~h}$ at $37^{\circ} \mathrm{C}$, the reaction was halted with the addition of a solution $(1000 \mu \mathrm{l})$ of phenol $(1 \mathrm{mM})$ and nitroprussiate $(0.17 \mathrm{mM})$, plus alkaline buffer $(1000 \mu \mathrm{l} ; 11 \mathrm{mM}$ $\mathrm{NaOCl}$ ). This solution (final volume of $2000 \mu \mathrm{l}$ ) was also added to the cuvettes with the different standard samples. Afterwards, the rate of change in absorbancy was determined. The ADA activity was estimated by interpolation from the standard curve described earlier. The reagents were stable at $2-8^{\circ} \mathrm{C}$ for 1 month.

\section{Drugs}

The following drugs were purchased as indicated: Evans Blue dye, carrageenan (degree IV), sodium azide, o-dianisidine $2 \mathrm{HCl}$ (3,3'-dimethoxybenzidine), human polymorphonuclear leukocyte MPO (Sigma), methotrexate (Wyeth, São Paulo, SP, Brazil), heparin (Liquemine ${ }^{\circledR} ;$ Roche, São Paulo, SP, Brazil), NaH${ }_{2} \mathrm{PO}_{4} \cdot \mathrm{H}_{2} \mathrm{O}, \mathrm{Na}_{2} \mathrm{HPO}_{4} \cdot 12 \mathrm{H}_{2} \mathrm{O}, \mathrm{NH}_{3} \mathrm{SO}_{4}$, nitroprussiate (Montedison, São Paulo, SP, Brazil), adenosine (Fluka,
Ronkonkoma, NY, USA), alkaline buffer (Merck, São Paulo, SP, Brazil), phenol (Biotech, São Paulo, SP, Brazil). $\mathrm{NaCl}(0.9 \%)$ and May-Grunwald-Giemsa dye were from different commercial sources. PBS (Merck) (pH 7.6; composition, $137 \mathrm{mmol}$ of $\mathrm{NaCl}, 2.7 \mathrm{mmol}$ of $\mathrm{KCl}$, and $10 \mathrm{mM}$ phosphate buffer salts) was previously prepared and maintained in the refrigerator. All drugs were kept in siliconized plastic tubes at $-20^{\circ} \mathrm{C}$. On the day of the experiments, the drugs were diluted to the desired concentration with sterile saline solution at room temperature.

\section{Statistical analysis}

Data is reported as the mean \pm SEM. Statistical differences between groups were determined by analysis of variance and complemented with Dunnet's and/or Student's tests. $p<0.05$ was considered indicative of significance.

\section{Results}

Figures $1 \mathrm{~A}$ and $1 \mathrm{~B}$ show that pre-treatment $(0.5$ and $24 \mathrm{~h}$, respectively) of the animals with different doses of methotrexate was associated with a significant decrease of leukocyte migration either at the early $(4 \mathrm{~h})$ or the late $(48 \mathrm{~h})$ phases of the studied inflammatory process. This inhibitory effect was not dose dependent. By contrast, methotrexate did not inhibit fluid leakage that occurs in the early phase $(4 \mathrm{~h})$ of this pleurisy model, but did at $48 \mathrm{~h}$ (Fig. 1A,B, inset).

Analysis of cell migration in the early $(4 \mathrm{~h})$ phase of this inflammatory reaction demonstrated that methotrexate caused a bimodal profile of the time-course kinetics $(20 \mathrm{mg} / \mathrm{kg}$, i.p., $0.5-24 \mathrm{~h}$ prior to pleurisy induction) (Fig. 2). As shown, according to the period of time chosen to administer this drug, an inhibitory effect was observed when it was given 0.5 or $24-48 \mathrm{~h}$ before, but not when it was given 1-12 h before. The degree of inhibition was directly related with neutrophil influx (Fig. 2, inset).

Although the inhibitory effect induced by methotrexate (1-40 mg/kg, i.p.) was not dose related, preliminary experiments (data not shown) had demonstrated that doses of 1-20 mg were ineffective in inhibiting nitrate/nitrite concentrations and MPO and ADA activities in the pleural leakage. Thus, the doses of 20 and $40 \mathrm{mg} / \mathrm{kg}$, i.p., of methotrexate and the pretreatment times of either 0.5 or $24 \mathrm{~h}$ were chosen to analyze nitrate/nitrite concentrations and also MPO and ADA activities in the pleural lavage ( 4 and $48 \mathrm{~h}$ after pleurisy induction, respectively). Analysis of these parameters $4 \mathrm{~h}$ after pleurisy induction (Fig. 3) shows that methotrexate $(20 \mathrm{mg} / \mathrm{kg}$, i.p.), when administered either 0.5 or $24 \mathrm{~h}$ before, caused a marked reduction of both nitrate/nitrite levels (Fig. 3A) and of MPO activity (Fig. 3B). Under the same 


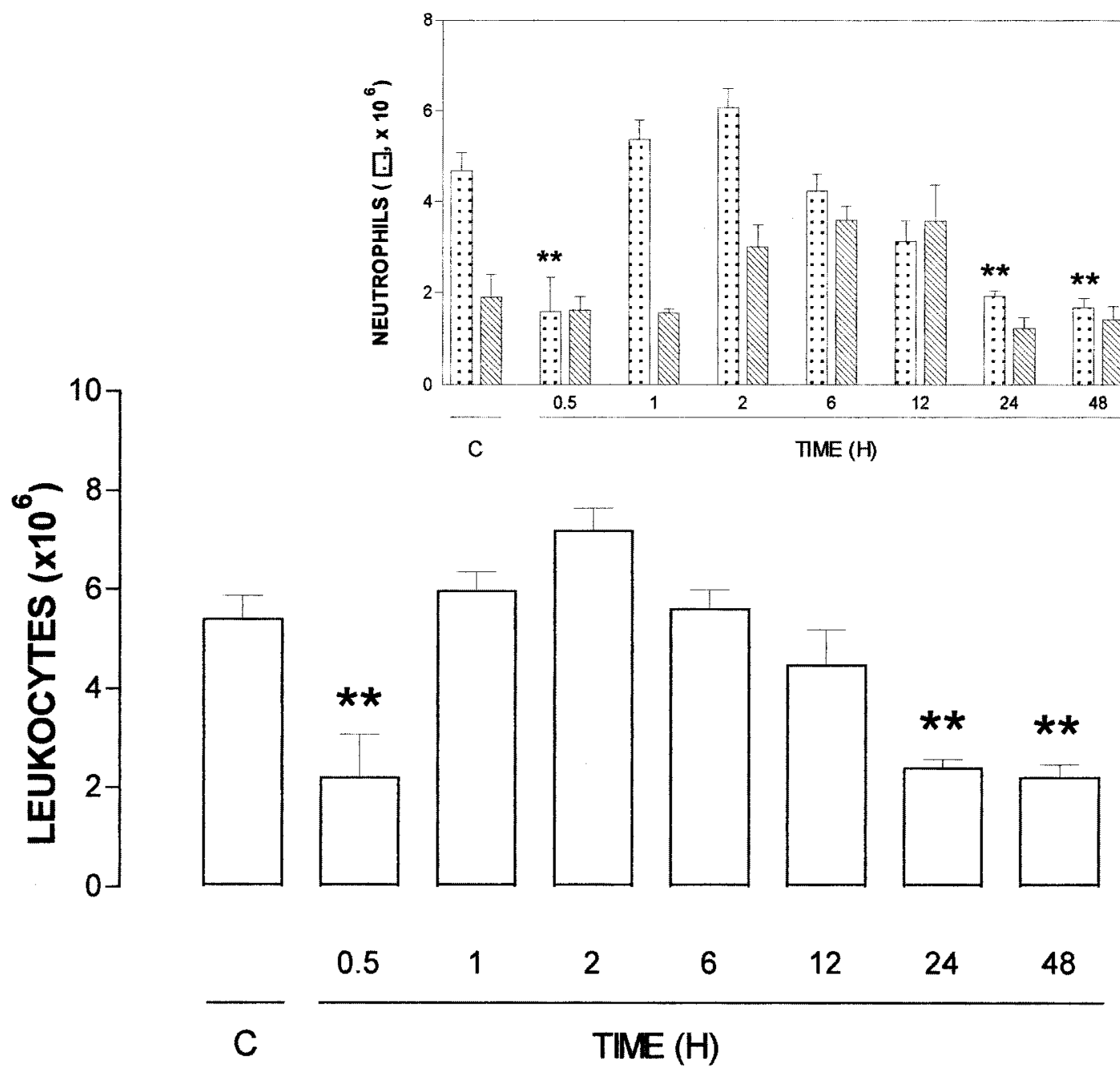

FIG. 2. Effect of methotrexate $(20 \mathrm{mg} / \mathrm{kg}$, i.p.) administered $05-48 \mathrm{~h}$ before carrageenan administration, on the early leukocyte migration $(4 \mathrm{~h})$ in the mouse pleural cavity. Inset: Effects of this drug on both neutrophils and mononuclears. $\mathrm{C}, \mathrm{Animals}$ treated only with carrageenan. Each group represents the mean of six to 10 animals, vertical bars represent the SEM. ${ }^{* *} p<0.01$.

experimental conditions, an enhancement of ADA activity was detected when methotrexate was administered $0.5 \mathrm{~h}$ before, but not $24 \mathrm{~h}$ before, pleurisy induction (Fig. 3C).

When the same inflammatory indices were analyzed $48 \mathrm{~h}$ after pleurisy induction (Fig. 4), all studied parameters were significantly reduced. As shown, methotrexate $(40 \mathrm{mg} / \mathrm{kg}$, i.p.) caused a significant decrease in the levels of nitrate/nitrite (Fig. 4A) and of both MPO (Fig. 4B) and ADA activities (Fig. 4C).

\section{Discussion}

The present data show that methotrexate is able to reduce the two pools of leukocyte populations that migrate to the pleural space at distinct periods of time ( 4 and $48 \mathrm{~h}$ ) after the induction of mouse pleurisy with carrageenan. Although this drug was acutely administered to the animals, it presented bimodal and long-lasting profiles characterized by two inhibitory effects that occurred early and late (pre-treatment times of 0.5 and $24 \mathrm{~h}$, respectively). This inhibition of cell influx into the pleural cavity was associated with a marked reduction of both MPO activity and nitrate/ nitrite concentrations. ADA activity that was significantly raised early after the induction of pleurisy ( $4 \mathrm{~h})$ presented a significant fall $48 \mathrm{~h}$ later.

It is interesting that the inhibitory effects induced by methotrexate upon cell migration in this model of pleurisy were not dose dependent. Furthermore, the inhibitory doses of this agent upon the studied inflammatory parameters clearly differed according to the studied variables. According to our protocol, doses of 1 and $10 \mathrm{mg} / \mathrm{kg}$ effectively inhibit cell migration 4 and $48 \mathrm{~h}$ after pleurisy induction. Furthermore, exudation of the early phase $(4 \mathrm{~h})$, but not of the late $(48 \mathrm{~h})$ phase, were not inhibited. In addition, only higher doses of methotrexate (20 and $40 \mathrm{mg} / \mathrm{kg}$, i.p.) were effective in inhibiting other inflammatory parameters such as MPO activity and nitrite/nitrate levels. These findings suggest that certainly there is a narrow range between anti- 

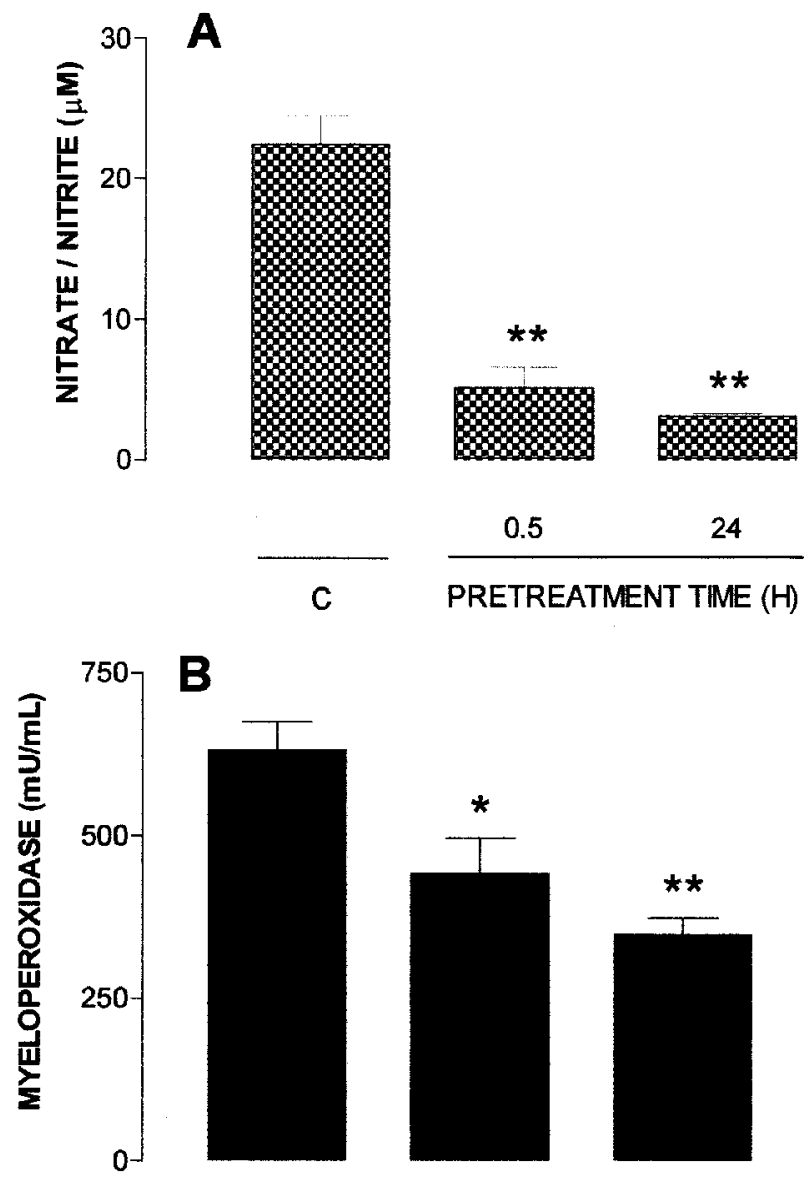

B

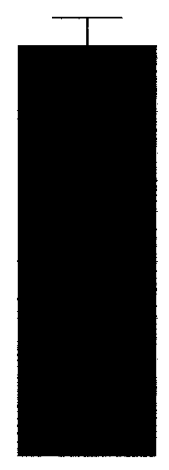

0.5

24

PRETREATMENT TIME (H)

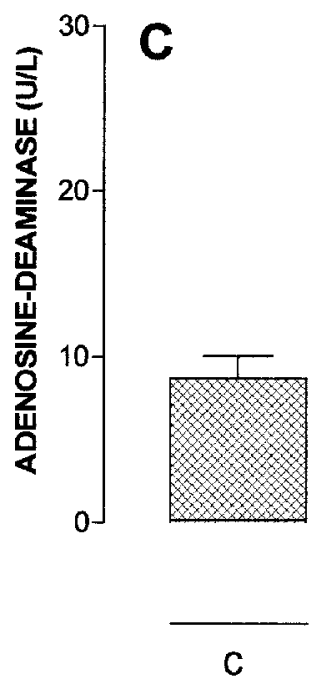

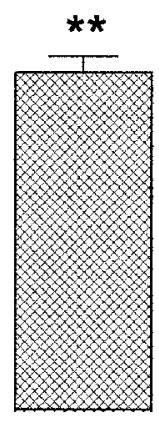

0.5

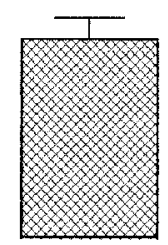

24

\section{PRETREATMENT TIME $(\mathrm{H})$}

FIG. 3. Effect of methotrexate $(20 \mathrm{mg} / \mathrm{kg}$, i.p.) on (A) nitrate/ nitrite levels, (B) myeloperoxidase and (C) adenosine-deaminase activities. All parameters were measured $4 \mathrm{~h}$ after pleurisy induction. C, Animals treated only with carrageenan. Each group represents the mean of six to 10 animals, vertical bars represent the SEM. ${ }^{*} p<0.05,{ }^{* *} p<0.01$.
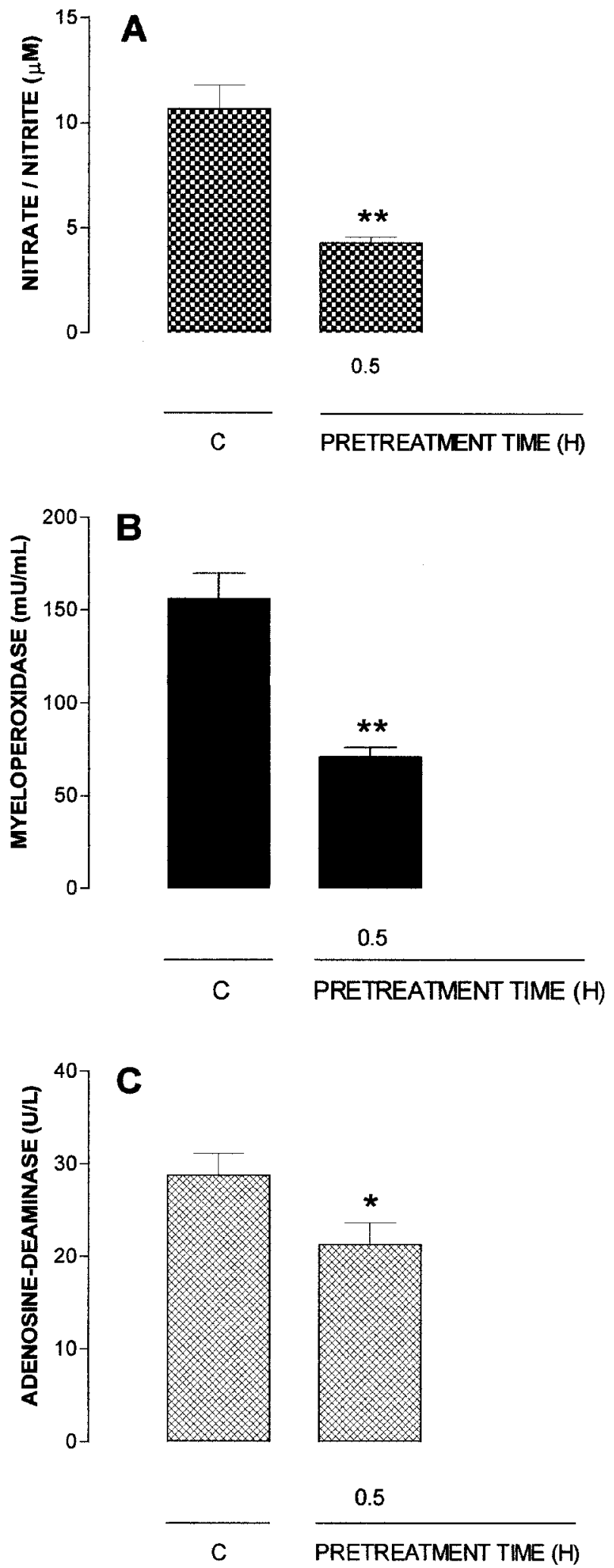

FIG. 4. Effect of methotrexate $(40 \mathrm{mg} / \mathrm{kg}$, i.p.) on (A) nitrate/ nitrite levels, (B) myeloperoxidase and (C) adenosine-deaminase activities. All parameters were measured $48 \mathrm{~h}$ after pleurisy induction. C, Animals treated only with carrageenan. Each group represents the mean of six to 10 animals, vertical bars represent the SEM. ${ }^{*} p<0.05,{ }^{* *} p<0.01$. 
inflammatory and immunossupressive effects attributed to this drug.

MPO, ADA and products of pathways that are mediated by iNOS have been widely recognized as powerful pathways implicated in several aspects of the inflammatory cascade including, among others, plasma exudation and cell migration. ${ }^{18}$ In this context, we have previously demonstrated that, in the studied model of inflammation, the levels of nitrite/ nitrate are significantly elevated at 4 and $48 \mathrm{~h}$, whereas increased levels of MPO are only observed in the early phase. ${ }^{12,14}$ The mechanisms by which methotrexate inhibits the inflammatory process have been studied in several models of inflammation where the production of NO via iNOS inductive pathways, among others, has been characterized. ${ }^{5,19,20}$ Thus, it was demonstrated that methotrexate caused a dose- and time-dependent inhibition of nitrate/nitrite produced by murine lung epithelial cells in vitro. ${ }^{5}$ Other studies, however, have shown that methotrexate does not affect NO production via iNOS induced in chondrocytes from either humans or rabbits. ${ }^{20,21}$ The findings of the present work indicating that methotrexate caused a significant reduction in nitrite/nitrate levels in both phases ( 4 and $48 \mathrm{~h}$ ) of this inflammatory reaction add support to the hypothesis that methotrexate's anti-inflammatory effects in this model may also be occurring via inhibition of NO generation.

Another pathway for this drug's anti-inflammatory effect is via inhibition of neutrophil migration to the site of inflammation due to its inhibitory effect upon cell-cell adhesion; namely, the expression of CD11b, CD18 molecules. $^{22}$ Since MPO activity is an indirect marker of activated neutrophil, the low MPO activity following methotrexate treatment could be explained by the inhibition of neutrophil influx. Based on these results, it is possible that methotrexate's inhibition of neutrophil influx may be linked with a decrease of adhesion molecules that facilitates such neutrophil influxes.

The effects of methotrexate upon ADA activity were also evaluated in this model. It is well demonstrated that this drug may increase the intracellular concentration of an enzyme (AICAR transformylase) required for de novo purine synthesis. ${ }^{23}$ This results in an increase in the release of adenosine, a potent antiinflammatory autacoid, at the site of inflammation. ${ }^{24}$ The subsequent interaction of adenosine with adenosine type 2 receptors may inhibit, among others, the expression of CD11b/CD18 molecules in leukocytes that promote and facilitate cell migration. ${ }^{25,26}$ To validate these findings, several in vitro studies have shown that ADA is able to suppress the effects of the released adenosine. In the present work, pre-treatment of the animals caused a reduction of the mononuclear cellular pool in association with a marked reduction of ADA activity. According to these results, the hypothesis that a decrease in ADA activity could favor the action of adenosine that was released by methotrexate at the site of the inflammatory reaction cannot be discarded. Otherwise, the fact that ADA activity remained elevated $4 \mathrm{~h}$ after pleurisy induction when methotrexate was administered $0.5 \mathrm{~h}$ before, but not $24 \mathrm{~h}$ before, indicates that methotrexate elicits its anti-inflammatory effects via other mediator pathways besides adenosine.

In summary, the present work presents evidence that the inhibitory effect of methotrexate upon both neutrophil and mononuclear cells is associated with a parallel decrease of NO production and of MPO activity. The results regarding the adenosine activity indirectly show that different mechanisms other than a direct action upon adenosine release contribute to this anti-inflammatory effect. Taken together, the experimental data indicates that the anti-inflammatory effects induced by methotrexate occurs via different mechanisms and is possibly dependent on the model of inflammation.

\section{Acknowledgments}

The authors would like to thank Mr J.A. Amaral for providing excellent technical support during the study, and the staff of the University Hospital Laboratory (Federal University of Santa Catarina, Brazil) for their kind cooperation.

\section{References}

1. Mitchell MS, Wade ME, DeConti RC, Bertino JR, Calabresi P. Immunossupressive effects of cytosine arabinoside and methotrexate in rheumatoid arthritis. Ann Intern Med 1969; 70: 535-548.

2. Weinblatt ME, Coblyn JS, Fox JS. Efficacy of low dose methotrexate in rheumatoid arthritis. $N$ Engl J Med 1985; 312: 818-822.

3. Costanzo-Nordin MR, Grusk BB, Silver MA, et al. Reversal of recalcitrant cardiac allograft rejection with methotrexate. Circulation 1988; 78: 47-57.

4. Chan GL, Weinstein SS, Vijayanagar RR. Treatment of recalcitrant cardiac allograft rejection with methotrexate. Clin Transp 1995; 9: 106-114.

5. Robbins RA, Jinkins PA, Bryan TW, Prado SC, Milligan SA. Methotrexate inhibition of inducible nitric oxide synthase in murine lung epithelial cells in vitro. Am J Respir Cell Mol Biol 1998; 18: 853-859.

6. Vergne P, Liagre B, Bertin P, Cook-Moreau J, Treves R, Beneytout JL, Rigaud M. Methotrexate and cyclooxygenase metabolism in cultured human rheumatoid synoviocytes. J Rheumatol 1998; 25: 433-440.

7. Yanaguimoto H, Ishizuki S, Fujihira E. Anti-inflammatory effects of methotrexate on reversed passive Arthus reactions in rats. Res Commun Mol Pathol Pharmacol 2000; 107: 377-386.

8. Cronstein BN, Naime D, Ostad E. The antiinflammatory mechanism of methotrexate. Increased adenosine release at inflamed sites diminishes leukocyte accumulation in an in-vivo model of inflammation. J Clin Invest 1993; 92: 2675-2682.

9. Morabito L, Montesinos MC, Schreibman DM, et al. Methotrexate and sulfasalazine promote adenosine release by a mechanism that requires ecto-5(-nucleotidase-mediated conversion of adenine nucleotides. J Clin Invest 1998; 15: 295-300.

10. Henriques MG. Estudo da Rea ão Inflamatória induzida por carragenina em camundongos. PhD. Thesis. Departamento de Fisiologia e Farmacodinâmica, Funda ão Oswaldo Cruz, Rio de Janeiro, Brazil. pp. 1-181.

11. Saleh TSF, Calixto JB, Medeiros YS. Anti-inflammatory effects of theophyl line, cromolyn and salbutamol in a murine model of pleurisy. $\mathrm{Br} J$ Pharmacol 1996; 118: 811-819.

12. Fröde TS, Medeiros YS. Myeloperoxidase and adenosine-deaminase levels in the pleural fluid leakage induced by carrageenan in the mouse model of pleurisy. Mediat Inflamm 2001; 10: 223-227.

13. Di Rosa M, Lalenti A, Ianaro A, Sautebin L. Interaction between nitric oxide and cyclooxygenase pathways. Prostaglandins Leukocyte Essential Fatty Acids 1996; 54: 229-238. 
14. Saleh TSF, Calixto JB, Medeiros YS. Effects of anti-inflammatory drugs upon nitrate and myeloperoxidase levels in the mouse pleurisy induced by carrageenan. Peptides 1999; 20: 949-956.

15. Sautebin L, Ialenti A, Ianaro A, Di Rosa M. Relationship between nitric oxide and prostaglandins in carrageenan pleurisy. Biochem Pbarmacol 1998; 55: 1113-1117.

16. Rao TS, Currie JL, Shaffer AL, Isakson PC. Comparative evaluation of arachidonic acid (aa)- and tetradecanoylphorbol acetate (tpa)-induced dermal inflammation. Inflammation 1993; 17: 723-741.

17. Giusti G, Galanti B. Adenosine deaminase: colorimetric method. In: Bergmeyer HU, ed. Methods of enzymatic analysis, New York: Verlac Chemie, 1984: 315-323.

18. Cuzzocrea S, Mazzon E, Calabro G, et al. Inducible nitric oxide synthaseknockout mice exhibit resistance to pleurisy and lung injury caused by carrageenan. Am J Respir Crit Care Med 2000; 162: 1859-1866.

19. Omata $\mathrm{T}$, Segawa $\mathrm{Y}$, Inoue $\mathrm{N}$, Tsuzuike $\mathrm{N}$, Itokazu $\mathrm{Y}$,Tamaki $\mathrm{H}$ Methotrexate supresses nitric oxide prodution ex vivo in macrophages from rats with adjuvant-induced arthritis. Res Exp Med 1997; 197: 81-90.

20. Hayem G, Domarle O, Thuong-Guyot M, Pocidalo JJ, Meyer O. Effects of methotrexate on the oxidative metabolism of cultured rabbit articular chondrocytes. J Rbeumatol 2000; 27: 1117-1120.

21. De Gendt CM, De Clerek LS, Bridts $\mathrm{CH}$, Verbruggen A, Stevens WJ. Influence of antirheumatic drugs on nitric oxide and interleukin-8 production in human articular chondrocytes. $J$ Rheumatol 1998; 25 536-538.

22. Ciesielski CJ, Mei J, Piccinini LA.Effects of cyclosporine A and methotrexate on CD18 expression in recipients of rat cardiac allografts. Transpl Immunol 1998; 6: 122-133

23. Cronstein BN, Naime D, Ostad E. The antiinflammatory effects of methotrexate are mediated by adenosine. Adv Exp Med Biol 1994; 370 : 411-416.

24. Cronstein BN, Montesinos MC, Weissmann G. Sites of action for future therapy: an adenosine-dependent mechanism by which aspirin retains its anti-inflammatory activity in ciclooxygenase -2 and NF-Kappa B knockout mice. Osteoarthritis Cartilage 1999; 7: 361-363.

25. Elliott KR, Miller PJ, Stevenson HC, Leonard EJ. Synergistic action of adenosine and Met-Leu-Phe in raising cAMP content of purified human monocytes. Biochem Biophys Res Commun 1986; 138: 1376-1382.

26. Leonard PA, Clegg DO, Carson CC, Cannon GW, Egger MJ, Ward JR. Low dose pulse methotrexate in rheumatoid arthritis: an 8-year experience with hepatotoxicity. Clin Rbeumatol 1987; 6: 575-582.

Received 30 May 2002

Accepted 10 July 2002 


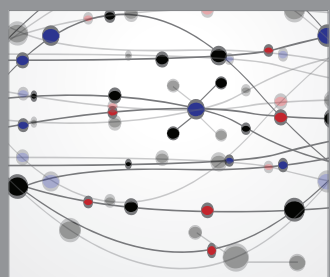

The Scientific World Journal
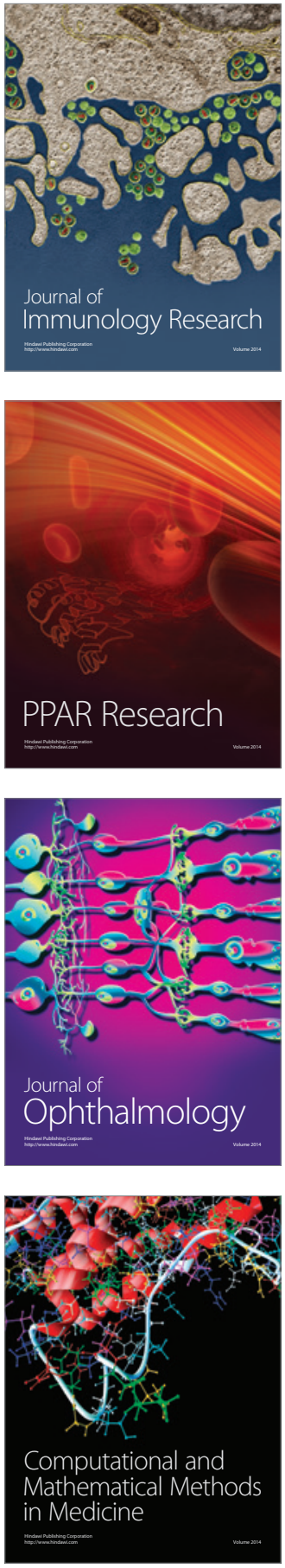

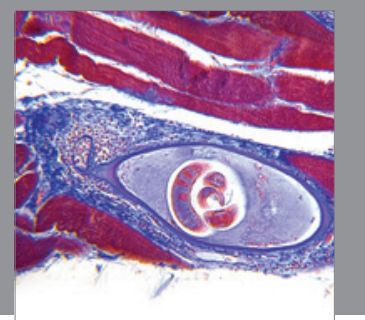

Gastroenterology

Research and Practice
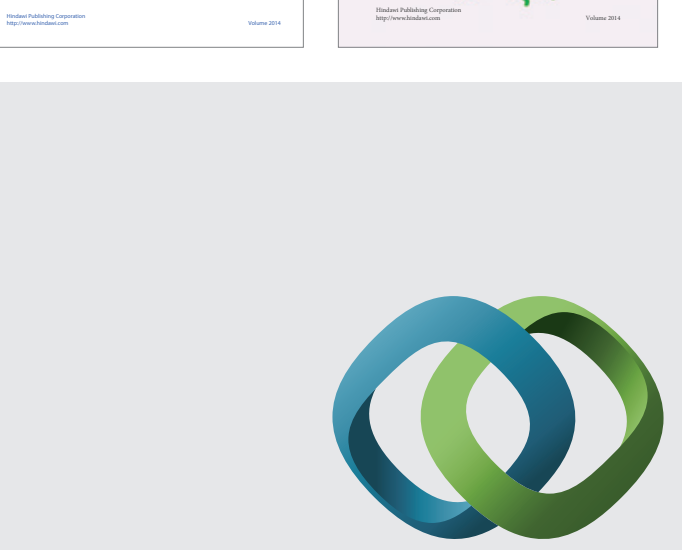

\section{Hindawi}

Submit your manuscripts at

http://www.hindawi.com
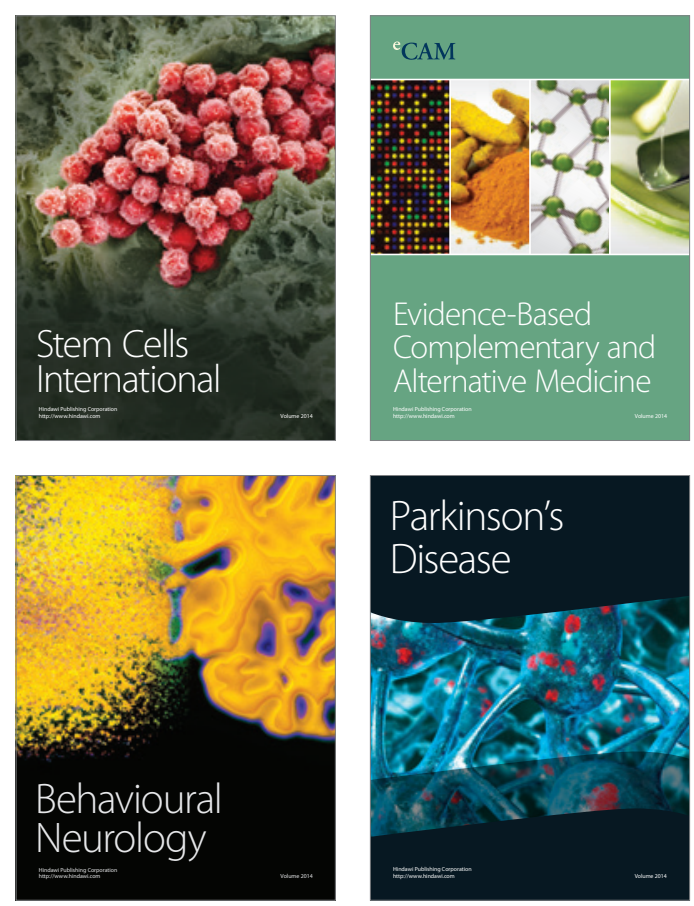

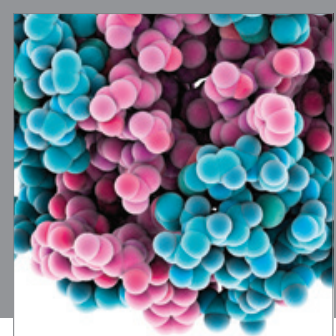

Journal of
Diabetes Research

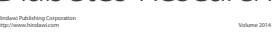

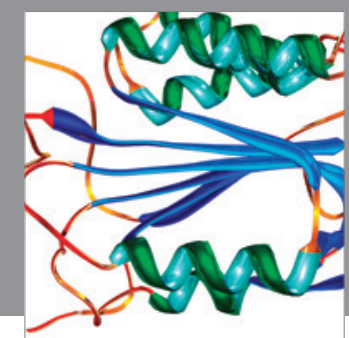

Disease Markers
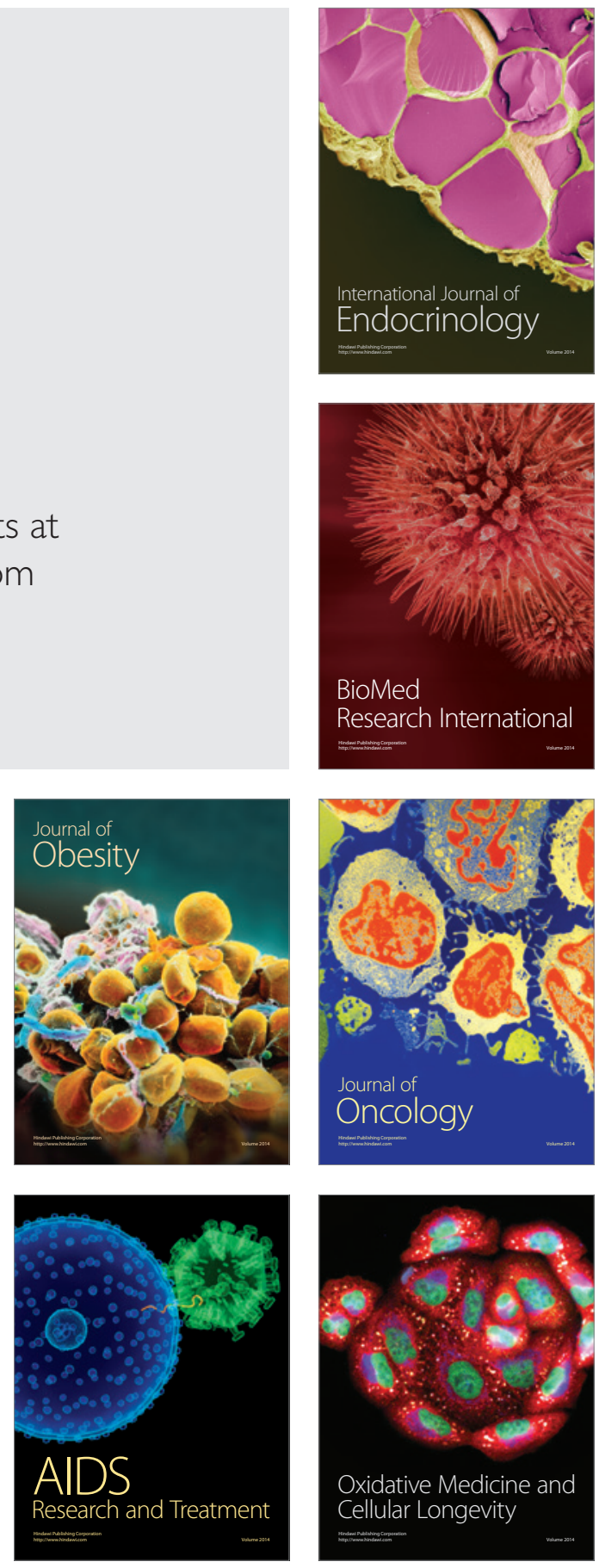